Pesq. Vet. Bras. 37(5):465-470, maio 2017 DOI: $10.1590 / \mathrm{S} 0100-736 \mathrm{X} 2017000500007$

\title{
Efficacy of an internal teat seal associated with a dry cow intramammary antibiotic for prevention of intramammary infections in dairy cows during the dry and early lactation periods ${ }^{1}$
}

\author{
Lívio R. Molina2*, Hudson. N. Costa ${ }^{3}$, Juliana M. Leão ${ }^{4}$, Victor M.R. Malacco ${ }^{4}$ \\ Elias J. Facury Filho ${ }^{2}$, Antônio U. Carvalho² and Camila F.A. Lage ${ }^{4}$
}

\begin{abstract}
Molina L.R., Costa H.N., Leão J.M., Malacco V.M.R., Facury Filho E.J., Carvalho A.U. \& Lage C.F.A. 2017. Efficacy of an internal teat seal associated with a dry cow intramammary antibiotic for prevention of intramammary infections in dairy cows during the dry and early lactation periods. Pesquisa Veterinária Brasileira 37(5):465-470. Escola de Veterinária, Universidade Federal de Minas Gerais, Av. Antônio Carlos 6627, Cx. Postal 567, Campus Pampulha, Belo Horizonte, MG 31270-901, Brazil. E-mail: Imolina@vet.ufmg.br

The present study aimed to evaluate the use of an internal dry period teat seal containing bismuth subnitrate $\left(\right.$ Teatseal $^{\circledR}$, Zoetis ${ }^{\circledR}$, Florham Park, Nova Jersey, USA) associated with a long-acting cloxacilin preparation (Orbenin ${ }^{\circledR}$ Extra dry cow, Zoetis ${ }^{\circledR}$, Florham Park, Nova Jersey, USA), in preventing new infections during the dry-off and early postpartum period. A total of 150 Holstein cows (average production of 9,000 kg of milk per lactation), with four functional udder quarters without clinical mastitis was included in the study. All animals were dried-off 60 days before the expected calving date. Two teats positioned diagonal-contralaterally received only dry cow antibiotic, control group $\mathrm{C}(\mathrm{n}=300)$ and the other two teats, treatment group $\mathrm{T}(\mathrm{n}=300)$ received dry cow antibiotic and infusion with an internal teat seal. Data from SCC variable were transformed by log base-10 transformation. Duncan's test was used accepting $5 \%$ as the level of statistical significance. The occurrence of intramammary infection (IMI) and chronicity rate, and frequency of microorganisms isolated at drying and immediately postpartum in teats of group C and group $\mathrm{T}$ were evaluated using a non-parametric Chi-square Test, accepting $10 \%$ as the statistical significance level. There was a decrease in the occurrence of new infections in the early postpartum in cows which the sealant was used $(\mathrm{C}=19.6 \%, \mathrm{~T}=11.4 \%)$. In the postpartum period, Gram-negative bacteria were isolated from 16 teats in $\mathrm{C}$ and seven in T. The greatest reduction was observed for Escherichia coli (8 vs 1) in group T. There was no effect using the internal sealant on the frequency of isolation of environmental Streptococus. The use of sealant reduced the prevalence of subclinical mastitis cows between drying-off and the early postpartum period $(\mathrm{C}=51 \%$ versus $\mathrm{T}=42 \%)$ and resulted in a lower somatic cell count (SCC) in the treatment group when compared with the control group $\left(\mathrm{T}=1,073 \times 10^{3}\right.$, $\mathrm{C}=1,793 \times 10^{3}$ ). The use of the internal teat seal combined with dry cow antibiotic is effective in the prevention of IMI during the dry period and early lactation and results in the reduction of SCC in immediate postpartum period. The treatment is effective in reducing infection between dry-off and the immediate postpartum caused by major and minor pathogens. However, no effect on infections caused by contagious pathogens was observed.
\end{abstract}

INDEX TERMS: Teat seal, antibiotic, lactation periods, mastitis, dry cow, environmental pathogens, SCC.

\footnotetext{
${ }^{1}$ Received on January 11, 2016

Accepted for publication on November 1, 2016.

${ }^{2}$ Departamento de Clínica e Cirurgia Veterinária, Escola de Veterinária, Universidade Federal de Minas Gerais (UFMG), Av. Antônio Carlos 6627, Cx. Postal 567, Campus Pampulha, Belo Horizonte, MG 341270-901, Brazil. *Corresponding author: Imolina@vet.ufmg.br
}

\footnotetext{
${ }^{3}$ Departamento de Medicina Veterinária, Pontifica Universidade Católica de Minas Gerais, Rua Rosário 1081, Angola, Betim, MG 32604-115, Brazil.

${ }^{4}$ Departamento de Zootecnia, Escola de Veterinária, UFMG, Av. Antônio Carlos 6627, Cx. Postal 567, Campus Pampulha, Belo Horizonte, MG 31270-901, Brazil.
} 
RESUMO.- [Eficácia de um selante interno de tetos associado a antibiótico de vaca seca na prevenção de infecções intramamárias no período seco e início de lactação em vacas leiteiras.] Objetivou-se avaliar o uso de um selante interno de tetos contendo subnitrato de bismuto (Teatseal ${ }^{\circledR}$, Zoetis ${ }^{\circledR}$, Florham Park, Nova Jersey, EUA) associado a um antibiótico de longa ação contendo cloxacilina (Orbenin ${ }^{\circledR}$ Extra dry cow, Zoetis ${ }^{\circledR}$, Florham Park, Nova Jersey, EUA) em prevenir novas infecções durante o período seco e pós-parto imediato. Foram utilizadas 150 vacas Holandesas (produção média de 9,000 kg de leite por lactação), com os quatro quartos mamários funcionais e sem mastite clínica, que foram secas 60 dias antes da data prevista para o parto. 0 teto constituiu a unidade experimental. O grupo controle (C) foi representado por dois tetos diagonais-contralaterais $(n=300)$, que receberam somente $\mathrm{o}$ antibiótico de vaca seca. Os outros dois tetos $(\mathrm{n}=300)$ constituíam o grupo tratado (T) e recebiam o antibiótico de vaca seca associado ao selante interno. Dados da variável contagem de células somáticas (CCS) passaram por transformação logarítmica na base 10 e foram submetidos ao teste de Duncan, aceitando-se nível de 5\% de significância estatística. A ocorrência de infecções intramamárias (IIM), taxa de cronicidade e frequência de microrganismos isolados na secagem e imediatamente pós-parto nos tetos do grupo controle e tratados com selante interno foram avaliados utilizando o teste não paramétrico qui-quadrado, aceitando 10\% de nível de significância. Houve redução na ocorrência de novas infecções no pós-parto imediato nos animais em que se utilizou o selante (C=19,6\%, $\mathrm{T}=11,4 \%)$. No período pós-parto, foram isolados microrganismos Gram-negativo de 16 tetos no C e sete no T. A maior redução ocorreu para Escherichia coli, (8 versus 1) no grupo T. Não houve efeito da utilização do selante interno na frequência de isolamento de Streptococcus ambientais. O uso do selante reduziu a prevalência de mastite subclínica das vacas no pós-parto imediato ( $\mathrm{C}=51 \%$ versus $\mathrm{T}=42 \%$ ) e resultou em menor CCS no grupo tratado $\left(\mathrm{T}=1.073 \times 10^{3}\right)$ quando comparado com o grupo controle $\left(\mathrm{C}=1.793 \times 10^{3}\right)$. 0 uso do selante interno combinado com antibiótico de vacas secas é eficaz na prevenção de infecções intramamárias no período seco e início de lactação e resulta na redução da CCS no período pós-parto imediato. 0 tratamento é eficaz na redução de infecção entre a secagem e o pós-parto imediato causada por patógenos maiores e menores. Entretanto, não tem efeito sobre infecções causadas por patógenos contagiosos.

TERMOS DE INDEXAÇÃO: Selante de tetos, antibiótico, vaca seca, infecções intramamárias, período seco, lactação, vacas leiteiras, mastite, patógenos ambientais, CCS.

\section{INTRODUCTION}

During the drying-off period, the mammary gland of dairy cows is more susceptible to new infections, especially during the early phase when the teat sphincter has not yet closed by the production of keratin plug, and at the late phase by the beginning of the colostrogenesis and sphincter opening (Green et al. 2004). The drying is the opportune moment to use antibiotics aiming at both treatment of pre-existing intramammary infections (IMI) and to prevent new infections that may occur at the beginning of the dry-off period. These IMI may manifest clinically or sub-clinically at early stage of the next lactation. In some circumstances, the use of antibiotics at this phase does not guarantee successful reduction of IMI in the subsequent lactation. This fact may occur due to low concentration of antibiotic in mammary tissue at the end of the drying period, or the non formation of a keratin plug that affects approximately $20 \%$ of the cows (Smith et al. 1985, Bradley \& Green 2001).

After drying, a keratin plug forms on the teat canal and acts as a physical and bacteriostatic barrier that aids to prevent new IMI. The capacity of producing this plug varies among animals. Approximately $50 \%$ of the teats may remain open for up to 10 days (Williamson et al. 1995), and $23 \%$ of the teats may remain open for up to 6 weeks of the dry-off period (Dingwell et al. 2003).

As an ancillary method to control this issue, the use of internal teat seals have been proposed. It mimics the physiological mechanism of sealing off the teat canal. Green et al. (2004), Berry \& Hillerton (2007), Runciman et al. (2010) and Baillargeon \& LeBlanc (2010) showed that the use of internal seal on teat cistern associated to the dry cow antibiotic was effective in preventing IMI and reducing new infections. These facts reflect positively on the reduction of somatic cell count (SCC) and cases of clinical mastitis in the first 100 days of lactation. The same effects were observed for postpartum heifers that received internal seals during pre-partum (Parker et al. 2007, 2008).

Therefore, the present study aimed to evaluate the efficacy of an internal teat seal associated to a dry cow antibiotic on prevention of IMI during dry-off and early lactation periods.

\section{MATERIALS AND METHODS}

\section{Herd management}

All procedures used were approved by the Ethics Committee of UFMG, under protocol n. 117/2011.

This study was conducted in a dairy farm with 1,500 lactating Holstein cows handled in a confinement system with a mean production of $9,000 \mathrm{~kg}$ of milk per lactation. The trial period covered the months from October to April, a time of high heat and humidity, with average rainfall and maximum temperature of $1,150 \mathrm{~mm}$ and $28.6^{\circ} \mathrm{C}$, respectively. The animals were confined in free stall the whole year, except in the dry period and pre-partum, where they were housed in pens without plant coverage.

\section{Animals and treatments}

The study included 150 cows that presented all four functional udder quarters with no clinical mastitis at the moment of drying, which occurred 60 days before the expected calving date. The teat consisted as the experimental unit. The control group (C) was represented by two diagonal-contralateral teats $(n=300)$ that received only a long-acting antibiotic preparation containing cloxacilin (Orbenin ${ }^{\circledR}$ Extra dry cow, Zoetis ${ }^{\circledR}$, Florham Park, Nova Jersey, EUA). The other two teats $(n=300)$ composed the treatment group $(\mathrm{T})$ and received the dry cow antibiotic associated to an infusion of the internal teat seal. The internal teat seal is composed of bismuth subnitrate in a paraffin base $\left(\right.$ Teatseal ${ }^{\circledR}$, Zoetis $^{\circledR}$, Florham Park, Nova Jersey, EUA), and it is applied under hygienic conditions as recommended by Crispie et al. (2004). From the 150 
cows selected in the experiment, 18 were excluded due to death caused by metabolic disease or other causes. Three animals were excluded from the experiment because they maintained the same isolated pathogen during the drying and postpartum periods, which was considered a chronic infection. In group C, 264 and 271 and for group T, 265 and 254 udder quarters, were evaluated at drying and immediately postpartum, respectively.

\section{Sampling protocol and product administration}

Milking routine procedures in the farm consisted of mug testing, pre dipping in iodine solution and drying in a singleservice paper. Teats were then disinfected using a cotton ball impregnated with $70 \%$ ethanol (w/v) and samples were manually collected in sterile flasks. At the time of dry-off, two milk samples were collected from each quarter, in which one was destined for SCC and the other for microbiological assay. Cows were then milked. After milking, teat extremities were re-disinfected and all udder quarters were treated with dry cow antibiotic. After this procedure, two of the diagonal-contralateral teats from each animal received the internal seal on the teat cistern. Following this, antisepsis of all four teats was performed as post dipping using an iodine based solution. Animals were taken to a pen, with no plant coverage, where they were kept until calving. Before the first milking postpartum, the internal seal of each teat was manually removed. After calving, the animals were housed in free-stalls bedded with sand. Milk samples from each teat were manually collected between the $4^{\text {th }}$ and $7^{\text {th }}$ day postpartum for SCC and microbiological assay, following the same protocol used at drying. Once the experimental unit is the quarter in each udder, changes in sampling day affects the overall SCC average, but not the comparison between treatments.

\section{SCC and microbiological analysis}

The milk destined for SCC analysis in both periods (dry-off and postpartum) was collected in a flask containing Bronopol (2-bromo-2-nitropropano-1,3-diol), immediately cooled and taken to the Laboratory of Milk Quality at the Veterinary School of UFMG. Samples were analysed in a flow cytometer (BentleySomacount 300). Samples for microbiological assays were collected in sterile flasks, frozen at $-20^{\circ} \mathrm{C}$ and sent to be processed at Vida Vet ${ }^{\circledR}$ Laboratory, Botucatu, São Paulo.

\section{Definition of terms used for analysis}

In order of determining the frequency of subclinical mastitis (SCM) at dry-off and immediately postpartum, threshold values of 200,000 cells $\mathrm{mL}^{-1}$ and 400,000 cells $\mathrm{mL}^{-1}$ of milk were considered, respectively (Dohoo \& Leslie 1991, Schepers et al. 1997, De Vlieghern et al. 2004). The rates of new infection and chronicity were calculated using 200,000 cells $\mathrm{mL}^{-1}$ and 400,000 cells $\mathrm{mL}^{-1}$ of milk as thresholds, respectively.

New infections. Cows that were considered healthy (SCC $<200,000$ cells $\mathrm{mL}^{-1}$ ) at dry-off and with SCM (SCC $\geq 400,000$ cells $\left.\mathrm{mL}^{-1}\right)$ at postpartum were classified as having new infections.
Chronic. Cows that were considered with SCM at drying and presenting SCC $\geq 400,000$ cells $\mathrm{mL}^{-1}$ at postpartum were classified as chronic carriers.

\section{Definitions on microbiological analysis}

Quarters that presented one or two microorganisms in the microbiological assay were considered positive, while three or more pathogens characterized a contaminated sample, leading to the removal of those samples from the study (Frequency of microorganisms = total number of animals infected/ total number of animals). The pathogens were divided according to Reyher et al. (2012) into major pathogens (Staphylococcus aureus, Streptococcus uberis, Streptococcus dysgalactiae, and coliforms) and minor pathogens (Corynebacterium bovis, Staphylococcus intermedius, Staphylococcus epidermidis, Staphylococcus saprophyticus).

\section{Statistical analysis.}

In all parameters, the Lilliefors and Bartlett tests were applied to verify assumptions of normal probability distribution and homoscedasticity of the data, respectively. The experiment was evaluated as a completely randomized design. Data from SCC variable were transformed by log base-10 transformation. In the evaluation of somatic cell count (SCC), Duncan's test was used in the statistical program SAEG 9.0 (2006), accepting 5\% as the level of statistical significance. The occurrence of IMI and chronicity rate, and frequency of microorganisms isolated at drying and immediately postpartum in teats of control group and treated with internal seal were evaluated using a non-parametric Chisquare Test, accepting $10 \%$ as the statistical significance level, using the statistic program i-STAT.

\section{RESULTS}

The frequencies of IMI on the quarters of group $\mathrm{C}$ and $\mathrm{T}$ at dry-off were $20.8 \%$ and $20 \%$, respectively ( $p=0.65$ ). However, when this parameter was evaluated at postpartum the values statistically differed from $19.6 \%$ for group $C$ to $11.4 \%$ for group $\mathrm{T}$ (Table 1).

The use of the internal seal did not result in a reduction of IMI caused by contagious mastitis pathogens ( $p=0.58)$.

No effect of treatment for environmental Streptococcus subgroup was observed. When Gram-negative pathogens were evaluated, a significant reduction of IMI on postpartum was found, in which 16 teats of group C were affected, and seven for group T. In this group of microorganisms, the greater reduction occurred for Escherichia coli with eight teats (control) and one teat (treatment group) infected $(p=0.02)$. From the infections caused by minor pathogens, coagulase-negative Staphylococcus (CNS) in group C represented $80 \%$ of the infection at drying and $71.4 \%$ at postpartum, while group T presented $83.3 \%$ and $81.8 \%$ at both times, respectively (Table 2).

Table 1. Total udder quarters evaluated and prevalence of infected quarters at the time of drying and immediately postpartum

\begin{tabular}{|c|c|c|c|c|c|c|}
\hline & \multicolumn{3}{|c|}{ Infection drying } & \multicolumn{3}{|c|}{ Infection postpartum } \\
\hline & Group T & Group C & $P$ & Group T & Group C & $P$ \\
\hline Quarters with no growth & 210 & 212 & & 214 & 225 & \\
\hline Infected quarters & 54 & 53 & & 57 & 29 & \\
\hline Total quarters evaluated & 264 & 265 & & 271 & 254 & \\
\hline Prevalence of quartes infected & $\begin{array}{c}20.8 \%^{\mathrm{a}} \\
(55 / 264)\end{array}$ & $\begin{array}{c}20 \% \%^{\mathrm{a}} \\
(53 / 265)\end{array}$ & 0.65 & $\begin{array}{c}19.6 \% \%^{\mathrm{a}} \\
(53 / 271)\end{array}$ & $\begin{array}{c}11.4 \%^{\mathrm{b}} \\
(29 / 254)\end{array}$ & 0.003 \\
\hline
\end{tabular}

Different letters differ by Chi-square Test $(\mathrm{p}<0.10)$. 
Table 2. Frequency of microorganisms isolated at drying and immediately postpartum in teats of control group and treated with internal seal

\begin{tabular}{|c|c|c|c|c|c|c|}
\hline \multirow[t]{2}{*}{ Species of Isolated Bacteria } & \multicolumn{3}{|c|}{ Infection drying } & \multicolumn{3}{|c|}{ Infection postpartum } \\
\hline & Group C & Group T & $P$ & Group C & Group T & $P$ \\
\hline Staphylococcus aureus & 12 & 13 & & 3 & 2 & \\
\hline Streptococcus agalactiae & 2 & 3 & & 8 & 7 & \\
\hline Total of contagious & 14 & 16 & 0.77 & 11 & 9 & 0.58 \\
\hline Streptococcus bovis & 5 & 0 & & 3 & 1 & \\
\hline Streptococcus uberis & 0 & 0 & & 1 & 0 & \\
\hline $\begin{array}{l}\text { Total of environmental } \\
\text { streptococcus }\end{array}$ & 5 & 0 & 0.01 & 4 & 1 & 0.12 \\
\hline Escherichia coli & 5 & 4 & & $8^{\mathrm{a}}$ & $1^{\mathrm{b}}$ & 0.02 \\
\hline Klebsiela Spp. & 2 & 2 & & 6 & 5 & \\
\hline Pseudomonas spp. & 1 & 3 & & 1 & 0 & \\
\hline Serratia macerans & 0 & 0 & & 1 & 0 & \\
\hline Enterobacter spp. & 0 & 0 & & 0 & 1 & \\
\hline Total of Gram-negative Pathogens & 8 & 9 & 0.85 & $16^{\mathrm{a}}$ & $7^{\mathrm{b}}$ & 0.05 \\
\hline Bacillus spp. & 2 & 4 & & 1 & 1 & \\
\hline Prototheca & 1 & 0 & & 0 & 0 & \\
\hline Total of major pathogens & 30 & 29 & 0.84 & $32^{\mathrm{a}}$ & $18^{\mathrm{b}}$ & 0.02 \\
\hline Corynebacterium bovis & 5 & 4 & & 6 & 2 & \\
\hline Staphylococcus intermedius & 3 & 1 & & 3 & 3 & \\
\hline Staphylococcus epidermidis & 16 & 18 & & 12 & 6 & \\
\hline Staphylococcus saprophyticus & 1 & 1 & & 0 & 0 & \\
\hline Total of minor pathogens & 25 & 24 & 0.94 & $21^{\mathrm{a}}$ & $11^{\mathrm{b}}$ & 0.02 \\
\hline Total of counted pathogens & 55 & 53 & 0.65 & $53^{a}$ & $29^{b}$ & 0.003 \\
\hline
\end{tabular}

Table 3. Mean of somatic cell count (SCC) and prevalence of subclinical mastitis in control group (C) and group treated (T) with seal at dry-off and postpartum

\begin{tabular}{lccccc}
\hline & \multicolumn{2}{c}{ Group C } & & \multicolumn{2}{c}{ Group T } \\
\cline { 2 - 3 } \cline { 5 - 6 } & Dry-off & Post-partum & & Dry-off & Post-partum \\
\hline Mean SCC (x 1000)* & $580^{\mathrm{a}}$ & $1793^{\mathrm{b}}$ & & $601^{\mathrm{a}}$ & $1073^{\mathrm{c}}$ \\
Subclinical 54\% $^{\mathrm{a}}$ & $51 \%^{\mathrm{a}}$ & $54 \%^{\mathrm{a}}$ & & $42 \%^{\mathrm{b}}$ & \\
prevalence $^{* *}$ & $(142 / 264)$ & $(138 / 271)$ & & $(144 / 265)$ & $(107 / 254)$
\end{tabular}

*Letters differ in the same row by Duncan Test at $5 \%, * *$ Chi-square $\mathrm{p}=0.10$.

Table 4. Rate of new infection and chronicity between control group (C) and treatment group (T)

\begin{tabular}{lccc}
\hline & $\begin{array}{l}\text { New infections (\%) } \\
\text { Pre-partum: SCC } \leq 200,000 / \mathrm{mL} \\
\text { Postpartum SCC }>400,000 / \mathrm{mL}\end{array}$ & $\begin{array}{l}\text { Chronicity }(\%) \\
\text { SCC }>400,000 / \mathrm{mL} \text { at } \\
\text { pre and postpartum }\end{array}$ & $p^{*}$ \\
\hline Group C & $50.50^{\mathrm{a}}$ & $55.60^{\mathrm{a}}$ & 0,10 \\
Group T & $40.70^{\mathrm{b}}$ & $45.80^{\mathrm{b}}$ & 0,10
\end{tabular}

*Means followed by different letters in the same column differ by Chi-square test $(\mathrm{p} \leq 0.10)$.

SCC was similar at dry-off between $\mathrm{C}$ and $\mathrm{T}$ groups. The prevalence of sub-clinical infection was $54 \%$ in both groups at drying. At postpartum, however, SCC of group T $\left(1,073 \times 10^{3}\right.$ cells $\left.\mathrm{mL}^{-1}\right)$ was significantly inferior to group C $\left(1,793 \times 10^{3}\right.$ cells $\left.\mathrm{mL}^{-1}\right)$ (Table 3 ).

At dry-off, group C presented $20.8 \%$ of teats infected and group T presented $20 \%$. At this moment, high SCC was observed for both groups.

For the group treated with internal teat seals, a lower rate of new infections $(40.7 \%)$, which means cows dried with SCC lower than 200,000 cells $\mathrm{mL}^{-1}$ and calved with SCC greater than 400,000 cells $\mathrm{mL}^{-1}$, was observed compared to group C (50.5\%). Regarding chronicity or cows that dried and calved with SCC greater than 400,000 cells $\mathrm{mL}^{-1}$, group T presented $45.8 \%$ and group C $55.6 \%$ (Table 4 ).

\section{DISCUSSION}

The number of udder quarters infected at dry-off did not differ between the two groups, which showed that the groups were balanced regarding infection prevalence at that moment.

The reduction in IMI at postpartum for group T proves that the infusion of the internal seal on teat cisterns had a significant effect in preventing infections during dry-off and immediately postpartum. This protecting effect of the seal is due to the mechanical barriers that reduce the access of environmental pathogens to the interior of the mammary gland, as highlighted by Godden et al. (2003).

These results are in agreement with different studies that observed lower infection rates in the group that received the internal seal (Berry \& Hillerton 2002, Godden et al. 2003, Bradley \& Green 2004, Green et al. 2004, Parker et al. 2007, 2008). Rabiee \& Lean (2013), in a meta-analysis study about the efficiency of internal seal associated or not to dry cow antibiotic, concluded that the use of internal seal reduces the risk of IMI by $25 \%$ immediately postpartum when compared to the use of only antibiotic during the dry off period.

The non-reduction of IMI caused by contagious agents can be explained by the low risk of transmission of contagious pathogens during the dry-off period, considering that the transmission mainly occurs at milking (Berry \& Hillerton 2002, Dingwell et al. 2003, Godden et al. 2003). Other studies highlight that the use of internal seals have no effect on contagious pathogens during the dry-off period, as less than $1 \%$ of new infections in this period are caused by these agents and $95 \%$ are caused by 
environmental pathogens (Dingwell etal. 2003). In this way, antibiotic therapy is the main source of elimination and control of infections caused by contagious microorganisms at this phase (Robert et al. 2006). Twomey et al. (2000) showed that the use of internal seal reduced the risk of new infections by $S$. aureus and Streptococcus dysgalactiae when associated to a bactericidal antibiotic.

As shown in Table 2, no effect of treatment was obtained for environmental Streptococcus subgroups, indicating that the use of internal seal was not effective in controlling IMI caused by these microorganisms and contradicting the data observed by several authors (Berry \& Hillerton 2002, Godden et al. 2003, Parker et al. 2007, 2008). Considering the low frequency of these pathogens at both dry-off and postpartum periods, there is an indication that the challenge was low at the time of the study or, even more specifically, in the dairy farm that the study was conducted. High temperature and humidity, according to some authors (Smith et al. 1985, Riekerink et al. 2007), favour the multiplication of another group of environmental pathogens, the coliforms. The number of teats infected by Escherichia coli was reduced from eight teats (group C) to one teat (group T) infected with significant difference between the groups $(p=0.02)$ and similarly to what was obtained by Huxley et al. (2002). The high challenge during the wet season may have facilitated bacterial penetration in the mammary gland between the beginning of the dry-off period and calving day in group C. Additionally, the exclusive use of antibiotic presents low efficiency in eliminating infections caused by Gram-negative pathogens, considering its low sensibility to antimicrobial, especially coliforms (Bradley \& Green 2001, Robert et al. 2006).

In group T, 16 quarters were infected by contagious pathogens (S. aureus and S. agalactiae) before dry-off. Microbiological culture of these same quarters in postpartum showed $100 \%$ of cure for these microorganisms, affirming cloxacilin $(250 \mathrm{mg})$ efficacy in eliminating infections acquired during lactation. Previous work using anhydrous cefalonium in dry cow therapy have cure rates above $90 \%$ for pre-existing infection by the same microorganism (Bradley et al. 2010, Ospina et al. 2016). Variations on climate, herd and prevalence of microorganisms can greatly impact the antibiotic efficacy (Bradley \& Green 2009), making difficult to compare results between experiments.

High prevalence of Staphylococcus epidermidis, belonging to coagulase-negative Staphylococcus (CNS) was observed, similarly to those described in cows (Godden et al. 2003, Church et al. 2008) and in heifers during prepartum (Parker et al. 2007). These authors highlighted that CNS are natural residents of teat skin and can opportunely infect the mammary gland, especially during the drying period. The use of seal limited the occurrence of infection by this group of pathogens during dry-off.

Godden et al. (2003) also verified a decrease in SCC values during postpartum of nimals treated with intramammary seal. High SCC at calving is related to reduction in milk production (Green et al. 2007, Tancin et al. 2007), reinforcing the importance of using internal seal as a limiting factor to the entry of microorganism in the udder and in the control of new infections (Berry \& Hillerton 2002, Godden et al. 2003, Berry \& Hillerton 2007, Parker et al. 2007, 2008). Animals that have infections caused by coliforms could remain with a high SCC, due to the persistence of inflammatory reaction after bacterial cure, which may occur spontaneously (Smith et al. 1985, Akers \& Thompson 1987). During postpartum, although $42 \%$ of the teats from group T were diagnosed with subclinical mastitis and presented high SCC values, only $11.4 \%$ of them were infected. For group $\mathrm{C}$ the same behaviour was observed, in which $19.6 \%$ of assays were positive. These results can be justified by the fact that sample collection was performed immediately postpartum, which is the period of colostrum production and lower milk volume. Therefore decreasing the dilution effect of SCC in the milk at this phase of lactation (Sargeant et al. 2001, Ontsouka et al. 2003, De Vliegher et al. 2004, Green et al. 2007).

The lower rate of new infections (40.7\%) during the dry-off period was observed for group $\mathrm{T}$ compared to group C (50.5\%), and reinforces the effect of the internal seal in preventing CNS, corroborating the results of other researchers (Berry \& Hillerton 2002, Godden et al. 2003, Bradley \& Green 2004, Berry \& Hillerton 2007). Group T presented a $45.8 \%$ chronicity rate for CNS and group C presented $55.6 \%$ between dry-off and postpartum periods $(p=0.10)$. The results agree with the protecting effect of seals against the invasion of microorganisms in the mammary gland during the dry-off period of the animals.

\section{CONCLUSIONS}

The use of internal teat seal combined with dry cow antibiotic is efficient in preventing intramammary infection during the dry-off period.

The use of the seal resulted in reduction of SCC immediately postpartum and reduced the infection caused by major and minor pathogens.

\section{REFERENCES}

Akers R.M. \& Thompson H.W. 1987. Effect of induced leucocyte migration on mammary cell morphology and milk component biosynthesis. J. Dairy Sci. 70:1685-1695.

Baillargeon P. \& Leblanc S.J. 2010. Clinical and economic effects of an internal teat sealant at dry-off on the incidence of clinical mastitis in early lactation. Bov. Pract. 44:1910-1920.

Berry E.A. \& Hillerton J.E. 2002. The effect of an intramammary teat steal on new intramammary infections. J. Dairy Sci. 85:2512-2520.

Berry E.A. \& Hillerton J.E. 2007. Effect of an intramammary teat steal and dry cow antibiotic in relation to dry period length on postpartum mastitis. J. Dairy Sci. 90:760-765.

Bradley A.J., Breen J.E., Payne B., Williams P. \& Green J. 2010. The use of a cephalonium containing dry cow therapy and an internal teat sealant, both alone and in combination. J. Dairy Sci. 93:1566-1577.

Bradley A.J. \& Green M.J. 2001. An investigation of the impact of intramammary antibiotic dry cow therapy on clinical coliform mastitis. J. Dairy Sci. 84:1632-1639.

Bradley A.J. \& Green M.J. 2004. The importance of nonlactating period in the epidemiology of intramammary infection and strategies for prevention. Vet. Clinics, Food Anim. Pract. 20:547-568.

Bradley A.J. \& Green M.J. 2009. Factors affecting cure when treating bovine clinical mastitis with cephalosporin-based intramammary preparations. J. Dairy Sci. 92:1941-1953. 
Church G.T., Fox L.K., Gaskins C.T., Hancock D.D. \& Gay M. 2008. The effect of a shortened dry period on intramammary infections during the subsequent lactation. J. Dairy Sci. 91:4219-4225.

Crispie F., Flynn J., Ross R.P., Hill C. \& Meaney W.J. 2004. Dry cow therapy with a non-antibiotic intramammary teat seal: a review. Irish Vet. J. 57:412-418

De Vliegher S., Laevens H., Barkema H.W., Dohoo I.R., Stryhn H., Opsomer G. \& Kruif A. 2004. Management practices and heifer characteristics associated with early lactation somatic cell count of Belgian dairy heifers. J. Dairy Sci. 87:4937-947.

Dingwell R.T., Kelton D.F. \& Leslie K.E. 2003. Management of the dry cow in control of peripartum disease and mastitis. Vet. Clin. N. Am., Food Anim. Pract. 19:235-265.

Dohoo I.R. \& Leslie K.E. 1991. Evaluation of changes in somatic cell counts as indicators of new intramammary infections. Prev. Vet. Med. 10:225-237.

Godden S., Rapnicki P., Stewart S., Fetrow J., Johnson A., Bey R. \& Farnsworth R. 2003. Effectiveness of an internal teat seal in the prevention of new intramammary infections during the dry and early-lactation periods in dairy cows when used with a dry cow intramammary antibiotic. J. Dairy Sci. 86:3899-3911.

Green M.J., Green L.E., Schukken Y.H., Bradley A.J., Peeler E.J., Barkema H.W., Haas Y., Collis V.J. \& Medley G.F. 2004. Somatic cell count distributions during lactation predict clinical mastitis. J. Dairy Sci. 87:1256-1264.

Green M.J., Bradley A.J., Medley G.F. \& Browne W.J. 2007. Cow, farm, and management factors during the dry period that determine the rate of clinical mastitis after calving. J. Dairy Sci. 90:3764-3776.

Huxley J.N., Green M.J., Green L.E. \& Bradley A.J. 2002. Evaluation of the efficacy of an internal teat sealer during the dry period. J. Dairy Sci. 85:551-561.

Ontsouka C.E., Bruckmaies R.M. \& Blum J.W. 2003. Fractionized milk composition during removal of colostrum and mature milk. J. Dairy Sci. 86:2005-2011.

Ospina P.A., Rota N., Locatelli C., Colombo L., Pollera C., Giacinti G., Bronzo V., Casula A., Arpinelli A., Brossette V., Facchi M., Patelli A., Ruggeri A., Barberio A., Potenza G., Nydam D.V. \& Moroni P. 2016. Randomized noninferiority field trial comparing 2 first-generation cephalosporin products at dry off in quarters receiving an internal teat sealant in dairy cows J. Dairy Sci. 99:1-13. (In publication)

Parker K.I., Compton C.W.R., Anniss F.M., Weir A., Heuer C. \& McDougall S.
2007. Subclinical and clinical mastitis in heifers following the use of a teat sealant precalving. J. Dairy Sci. 90:207-218.

Parker K.I., Compton C.W.R., Anniss F.M., Heuer C. \& McDougall S. 2008. Quarter-level analysis of subclinical and clinical mastitis in primiparous heifers following the use of a teat sealant or an injectable antibiotic, or both, precalving. J. Dairy Sci. 91:169-181.

Rabiee A.R. \& Lean I.J. 2013. The effect of internal teat sealant products (Teatseal and Orbeseal) on intramammary infection, clinical mastitis, and somatic cell counts in lactating dairy cows: a meta-analysis. J. Dairy Sci. 96:6915-6931.

Riekerink R.G.M.O., Barkema H.W. \& Stryhn H. 2007. The effect of season on somatic cell count and the incidence of clinical mastitis. J. Dairy Sci. 90:1704-1715.

Robert A., Seegers H. \& Bareille N. 2006. Incidence of intramammary infections during the dry period without or with antibiotic treatment in dairy cows - a quantitative analysis of published data. Vet. Res. 37:25-48.

Runciman D.J., Malmo J. \& Deighton M. 2010. The use of an internal teat sealant in combination with cloxacillin dry cow therapy for the prevention of clinical and subclinical mastitis in seasonal calving dairy cows. J. Dairy Sci. 93:4582-4591.

Sargeant J.M., Leslie K.E., Shirley J.E., Pulkrabek B.J. \& Lim G.H. 2001. Sensitivity and specificity of somatic cell count and California mastitis test for identifying intramammary infection in early Lactation. J. Dairy Sci. 84:2018-2024.

Schepers A.J., Lam T.J.G.M. \& Schukken Y.H. 1997. Estimation of variance components for somatic cell counts to determine thresholds for uninfected quarters. J. Dairy Sci. 80:1833-1840.

Smith K.L., Todhunter D.A. \& Shoenberger P.S. 1985. Symposium: environmental effects on cow health and performance. J. Dairy Sci. 68:15311553.

Tancin V., Ipema A.H. \& Hogewerf P. 2007. Interaction of somatic cell count and quarter milk flow patterns. J. Dairy Sci. 90:2223-2228.

Twomey D.P., Wheelock A.I., Flynn J., Meaney W.J., Hill C. \& Ross R.P. 2000. Protection Against Staphylococcus aureus Mastitis in Dairy Cows Using a Bismuth-Based Teat Seal Containing the Bacteriocin, Lacticin 3147. J. Dairy Sci. 83:1981-1988.

Williamson J.H., Woolford M.W. \& Day A.M. 1995. The prophylactic effect of a dry cow antibiotic against Streptococcus uberis. New Zealand Vet. J. 43:228-234. 